\title{
Infection Risk Assessment of COVID-19 through Aerosol Transmission: a Case Study of South China Seafood Market
}

\author{
Xiaole Zhang, ${ }^{\#}$ Zheng Ji, ${ }^{\#}$ Yang Yue, Huan Liu, and Jing Wang* \\ Cite This: Environ. Sci. Technol. 2021, 55, 4123-4133 \\ Read Online
}

ABSTRACT: The Corona Virus Disease 2019 (COVID-19) is rapidly spreading throughout the world. Aerosol is a potential transmission route. We conducted the quantitative microbial risk assessment (QMRA) to evaluate the aerosol transmission risk by using the South China Seafood Market as an example. The key processes were integrated, including viral shedding, dispersion, deposition in air, biologic decay, lung deposition, and the infection risk based on the dose-response model. The available hospital bed for COVID-19 treatment per capita $\left(1.17 \times 10^{-3}\right)$ in Wuhan was adopted as a reference for manageable risk. The median risk of a customer to acquire SARS-CoV-2 infection via the aerosol route after $1 \mathrm{~h}$ of exposure in the market with one infected shopkeeper was about $2.23 \times 10^{-5}\left(95 \%\right.$ confidence interval: $1.90 \times 10^{-6}$ to $2.34 \times 10^{-4}$ ). The upper bound could increase and become close to the manageable risk with multiple infected shopkeepers. More detailed risk assessment should be conducted in poorly ventilated markets with multiple infected cases. The uncertainties were mainly due to the limited information on the dose-response relation and the viral shedding which Quantitative Microbial Risk Assessment for SARS-CoV-2 Aerosol Transmission need further studies. The risk rapidly decreased outside the market due to the dilution by ambient air and became below $10^{-6}$ at $5 \mathrm{~m}$ away from the exit.

\section{INTRODUCTION}

The atypical pneumonia-Corona Virus Disease 2019 (COVID-19) is rapidly spreading throughout the world. The World Health Organization (WHO) has declared the outbreak of COVID-19 as pandemic. The causal pathogen, severe acute respiratory syndrome coronavirus 2 (SARS-CoV-2), is a newly isolated coronavirus, which first massively spread in the South China Seafood Market in Wuhan. This is the third large-scale epidemic caused by coronaviruses in the last two decades after Severe Acute Respiratory Syndrome (SARS) in 2003 and Middle East Respiratory Syndrome (MERS) during 2012, 2015 and 2018.

There is still uncertainty about the transmission route of the SARS-CoV-2. According to the New Coronavirus Pneumonia Diagnosis and Treatment Plan (Trial Version 7) published by Chinese National Health Commission on March 3, 2020, ${ }^{1}$ the main human-to-human transmission routes are close contacts (direct/indirect) and large respiratory droplets by coughs or sneezes or droplets of saliva, but the aerosol and fecal-oral transmission could not be excluded and need further investigation. Different from large droplets, the aerosols are particles small enough to suspend in the air for prolonged time, normally with an aerodynamic diameter less than $10 \mu \mathrm{m}$, and often referred to as "droplet nuclei." It was shown that $87 \%$ of the exhaled particles were below $1 \mu \mathrm{m}$. ${ }^{3}$ There was potential evidence for the aerosol transmission route of SARS. ${ }^{4}$ Studies have suggested that aerosols could be an important mode of transmission for influenza over both short and longer distances. $^{5-7}$ However, the issue of long-range infection is still contentious, since the risk of long-range transmission by aerosols is dependent on the amount of the virus-containing particles, biologic decay, and infectious dose. ${ }^{6,8}$

In the current situation, great efforts have already been taken to prevent the transmission by contacts and droplets, e.g., washing hands and social distancing. A recent study has detected SARS-CoV-2 in aerosols. ${ }^{9}$ However, the role of the aerosol transmission is still uncertain. A thorough assessment of aerosol transmission risk is required to better understand and control its influences. Quantitative Microbial Risk Assessment (QMRA) is an effective methodology to estimate the risk of infectious diseases. QMRA has been utilized to investigate the inhalation health risk of pathogens generated

Special Issue: Environmental Transmission and Control of COVID-19

Received: May 6, 2020

Revised: June 15, 2020

Accepted: June 16, 2020

Published: June 16, 2020

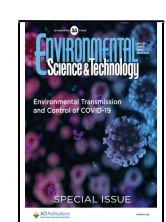


from reused water ${ }^{10,11}$ and waste management facilities for livestock farms. ${ }^{12,13}$ Recently, the QMRA method has been adopted to investigate the airborne infection risk of MERS$\mathrm{CoV}$ in a hospital, which indicated that the daily mean risk of infection for the nurses and healthcare workers was relatively high $\left(>10^{-4}\right) \cdot{ }^{14}$ Atmospheric dispersion models were utilized in the QMRA studies ${ }^{15}$ for foot-and-mouth-disease virus, ${ }^{16-21}$ avian influenza virus, ${ }^{22,23}$ Legionella, $^{24}$ the spore-forming bacterium B.anthracis, ${ }^{25-27}$ and the C. burnetii bacterium for Q fever. ${ }^{28,29}$ The atmospheric dispersion models ${ }^{30-32}$ estimate the temporal and spatial distribution of hazardous pollutants for a large scale and long period, which is difficult to achieve by field sampling and measurements. ${ }^{33-36}$ Biologic decays were normally included in the models. ${ }^{15}$

In this study, we evaluated the infection risk of SARS-CoV-2 induced by aerosol transmission during the initial phase of the spread in the South China Seafood Market in December 2019 based on the QMRA method, by assuming one infected shopkeeper working inside Street No. 7 and by integrating the best available information about the virus as well as their uncertainties. A zone model ${ }^{37}$ and a three-dimensional Lagrangian dispersion model ${ }^{38}$ were utilized to estimate the airborne virus concentration and exposure in the market and outdoor environments. The key processes were integrated into the assessment, including viral shedding, dispersion in air, deposition, biologic decay, and lung deposition. The infection risk was assessed using the dose-response model developed for SARS-CoV. ${ }^{39}$ Monte Carlo simulations are conducted to take into account the uncertainties in viral shedding, biologic decay, and the dose-response parameters. The infection risk by aerosol transmission was quantified for people in various scenarios, e.g., costumers and shopkeepers inside the market and pedestrians near the market and at the neighboring area hundreds of meters away from the market. The infection risks due to close contact (direct/indirect) and large respiratory droplets by coughs or sneezes or droplets of saliva were not included in this study.

\section{MATERIALS AND METHODS}

2.1. Scenario of South China Seafood Market. The assessment focused on the Wuhan South China Seafood Market (Figure 1), where the virus massively spread during the initial phase. The market is about $50000 \mathrm{~m}^{2}$ (https://zh. wikipedia.org/) with more than 1000 shops distributed in 12 commercial streets of the east district and 15 commercial streets of the west district. The streets are almost isolated from each other, only connected by an aisle as shown in Figure 1c. The ventilation system inside the market had not been used for years, ${ }^{40}$ so it was assumed that the air exchange inside the market was only dependent on natural ventilation.

The market-related infected cases contributed about 55\% (26/47) to the total reported number before January 1, 2020, when the market was closed. ${ }^{41}$ The onset of illness of the first market related case was on December 13, 2019. ${ }^{41}$ The virus might have already spread inside the market at the beginning of December considering the normal incubation period of about 2 weeks. As a result, the assessment covered the whole December of 2019.

According to Chinese Center for Disease Control and Prevention (China CDC), about $42.4 \%$ of the positive environmental samples for SARS-CoV-2 were from Street No. 7 and No. $8,^{42}$ which are shown in Figure 1c. The spatial distribution of the infected cases is still uncertain. In this study, (a)

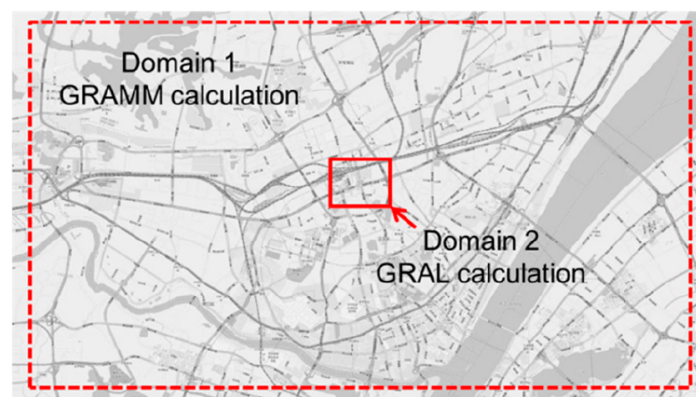

(b)

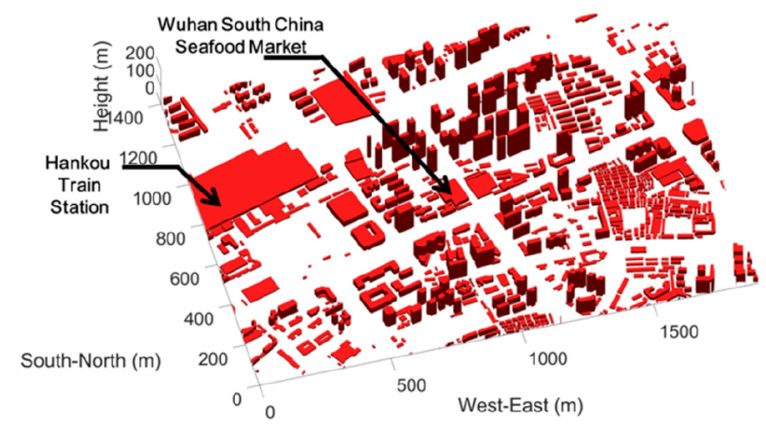

(c)

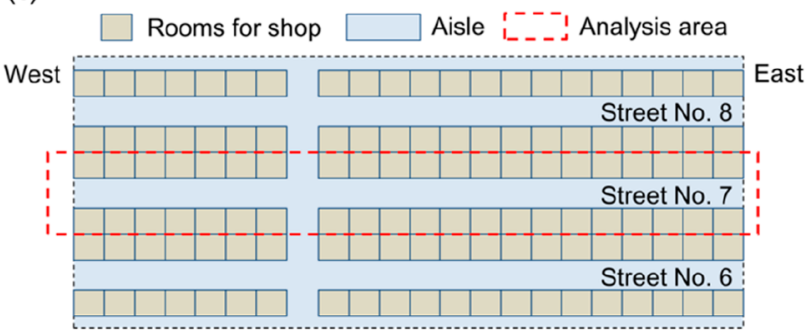

Figure 1. Computation domain of the study. (a) Nested domain was utilized to calculate the detailed wind field near the South China Seafood Market: outer domain for the mesoscale numerical weather prediction model GRAMM (Graz Mesoscale Model wind fields) and inner domain for GRAL (microphysics Graz Lagrangian Model). (b) The GRAL calculation domain for the wind field and atmospheric dispersion in the area populated by buildings. The shielding effects of the surrounding buildings have been considered. (c) The calculation domain for the zone model, which was developed and utilized to calculate the aerosol transport and deposition inside the market.

it was assumed that there was one infected person inside Street No. 7 working from 6:00 to 18:00 every day, and the air flow was dominantly along the street due to the symmetrical structure of the market. After the simplification, the virus concentration was only calculated in the area defined by the red dashed line in Figure 1c. The geometrical dimension of the market was estimated from the satellite images and the street photos. The length and width of each street were respectively about 70 and $9 \mathrm{~m}$, with a height of $5 \mathrm{~m}$. The sizes of the entrances for the street were about $3 \mathrm{~m}$ in width and $2.5 \mathrm{~m}$ in height.

2.2. Viral Shedding from Infected Person. The virus concentration of SARS-CoV during the growth of post infection was about $10^{5}$ to $10^{7}$ plaque-forming units per $\mathrm{mL}$ $\left(\mathrm{PFU} \mathrm{mL} \mathrm{mL}^{-1}\right)^{43}$ in the respiratory fluid from the apical surface of the human airway epithelial cell culture system (HAE), which is an in vitro model of the human airway epithelium. A similar level of MERS-CoV concentration was also found in the HAE system. ${ }^{44}$ It is reasonable to assume SARS-CoV-2 has 
a similar concentration. If the virus concentration is homogeneous in the respiratory fluid, the total viral shedding $E_{\text {virus }}$ can be estimated as

$$
E_{\text {virus }}=\sum_{i=1}^{n} N_{i} \times \frac{1}{6} \pi d_{0, i}^{3} \times C_{\text {virus }}
$$

where $C_{\text {virus }}$ is the viral concentration in the respiratory fluid, $N_{i}$ is particle number in size bin $i$, and $d_{0, i}$ is the diameter of the expelled fresh droplets before evaporation.

The aerodynamic diameters of the particles generated by breathing were mainly below $5 \mu \mathrm{m}$, and they had already achieved an equilibrium state after evaporation, ${ }^{45}$ with a diameter of $d_{\text {eq }}$. The number concentrations of the expelled droplet nuclei were about 0.098 particles $\mathrm{cm}^{-3}$ for mouth breathing, ${ }^{45}$ including four size bins $\left(d_{\mathrm{eq}}\right): 0$ to $0.8 \mu \mathrm{m}(0.084$ $\left.\mathrm{cm}^{-3}\right), 0.8$ to $1.8 \mu \mathrm{m}\left(0.009 \mathrm{~cm}^{-3}\right), 1.8$ to $3.5 \mu \mathrm{m}(0.003$ $\left.\mathrm{cm}^{-3}\right)$, and 3.5 to $5.5 \mu \mathrm{m}\left(0.002 \mathrm{~cm}^{-3}\right)$. The tidal volume was set as $500 \mathrm{~mL}$ per inspiration, and 20 inspirations per minute for an adult. ${ }^{46}$ The relation between the initial droplet diameter $d_{0}$ and the diameter of the equilibrium droplet nuclei $d_{\text {eq }}$ was estimated following the method proposed by Nicas et al., 47 assuming that the solute in the respiratory fluid was dominated by ions:

$$
d_{\mathrm{eq}}=0.16 \times d_{0}
$$

The virus concentration in respiratory fluid $C_{\text {virus }}$ was treated as a stochastic variable in this study. Based on the experimental data, ${ }^{43,44} C_{\text {virus }}$ was assumed to follow a log-normal distribution $\log _{10}\left(C_{\text {virus }}\right) \sim N(6,0.3)$. The estimated concentration by the log-normal distribution was mainly between $10^{5}$ and $10^{7} \mathrm{PFU}$ $\mathrm{mL}^{-1}$. Monte Carlo simulations were conducted to incorporate the influences of the uncertain concentrations into the uncertainties of the final infection risk assessment. The estimated viral shedding was mostly between 1 and $10^{3} \mathrm{PFU}$ per hour, comparable to the shedding of infectious influenza virus with a geometric mean of 37 fluorescent focus units (FFU), a similar unit to PFU, per $30 \mathrm{~min}$ sample of fine aerosol with aerodynamic diameter below $5 \mu \mathrm{m}$, measured during natural breathing and prompted speed. ${ }^{48} \mathrm{~A}$ recent study ${ }^{49}$ investigated the respiratory shedding of coronavirus (NL63, OC43, HKU1, and 229E) in exhaled breath, and the results indicated that there were $10^{2}$ to $10^{5}$ virus copies in the aerosol particles below $5 \mu \mathrm{m}$ collected for $30 \mathrm{~min}$ without wearing masks. A previous study on SARS-CoV ${ }^{50}$ showed that about 300 viral genome copies were present per PFU. As a result, our estimations are about $3 \times 10^{2}$ to $3 \times 10^{5}$ copies per hour, which agrees well with a recent study. ${ }^{49}$ It should be noted that about $30 \%$ to $56 \%$ of the total collected samples were positive in the aforementioned virus shedding studies. ${ }^{48,49}$ We assumed all the infected persons would shed virus, which may lead to overestimation of the risk, but it is reasonable to keep some safety margins.

2.3. Biologic Decay of Coronavirus in Ambient Environments. Only one study is available for the biologic decay of SARS-CoV-2, ${ }^{51}$ which indicated that the half-lives of SARS-CoV-2 and SARS-CoV were similar in aerosols, about 1.1 to $1.2 \mathrm{~h}$ at $21-23{ }^{\circ} \mathrm{C}$ and $65 \%$ relative humidity. However, biologic decay may depend on the ambient conditions. The decay information reported in the literature for other coronaviruses, including common human coronavirus ( $\mathrm{HCoV})$, MERS-CoV, SARS-CoV, transmissible gastroenteritis virus (TGEV), and mouse hepatitis virus (MHV) were collected as shown in Table 1 , to evaluate the uncertainties of this parameter.

Table 1. Biologic Decay of Corona Viruses Reported in the

\begin{tabular}{|c|c|c|c|c|c|c|}
\hline no. & virus type & $\begin{array}{l}\text { half-life } \\
\text { (hours) }\end{array}$ & medium & temperature & $\begin{array}{l}\text { relative } \\
\text { humidity }\end{array}$ & ref \\
\hline 1 & SARS-CoV-2 & $1.1-1.2^{a}$ & air & $21-23^{\circ} \mathrm{C}$ & $65 \%$ & 51 \\
\hline 2 & $\begin{array}{l}\text { human } \\
\text { coronavirus } \\
229 \mathrm{E} \\
(\mathrm{HCoV})\end{array}$ & $3.34^{a}$ & air & $20^{\circ} \mathrm{C}$ & $80 \%$ & 52 \\
\hline 3 & $\mathrm{HCoV}$ & $67.33^{a}$ & air & $20{ }^{\circ} \mathrm{C}$ & $50 \%$ & 52 \\
\hline 4 & $\mathrm{HCoV}$ & $26.76^{a}$ & air & $20{ }^{\circ} \mathrm{C}$ & $30 \%$ & 52 \\
\hline 5 & $\mathrm{HCoV}$ & $86.01^{a}$ & air & $6{ }^{\circ} \mathrm{C}$ & $80 \%$ & 52 \\
\hline 6 & $\mathrm{HCoV}$ & $102.53^{a}$ & air & $6^{\circ} \mathrm{C}$ & $50 \%$ & 52 \\
\hline 7 & $\mathrm{HCoV}$ & $34.46^{a}$ & air & $6{ }^{\circ} \mathrm{C}$ & $30 \%$ & 52 \\
\hline 8 & MERS-CoV & $0.5^{b}$ & air & $38^{\circ} \mathrm{C}$ & $24 \%$ & 53 \\
\hline 9 & MERS-CoV & $2.0^{b}$ & air & $25^{\circ} \mathrm{C}$ & $79 \%$ & 53 \\
\hline
\end{tabular}
Literature

${ }^{a}$ The directly reported values. ${ }^{b}$ Estimated values based on the decay curves.

The half-life periods were from $0.5 \mathrm{~h}$ to $10^{2} \mathrm{~h}$ as shown in Table 1. The data indicated that a low temperature was normally favorable for viruses to survive in the air, but the role of relative humidity $(\mathrm{RH})$ was more complicated. It seemed that there was an optimal $\mathrm{RH}$ for the virus to survive, which was about $50 \%$ implied for the $\mathrm{HCoV} .{ }^{52}$ Higher or lower RHs might enhance the inactivation of the viruses. However, more data are still needed to confirm the $\mathrm{RH}$ effects. Considering the relatively wide range, the half-life periods were treated as a stochastic variable following the triangular distribution in this study. On the basis of the available data in Table 1, the lower limit, upper limit, and mode of the distribution were respectively set as $\log _{10}(0.5), \log _{10}(100)$, and $\log _{10}(10)$. Halflife periods were sampled following a triangular distribution and utilized by the Monte Carlo simulations.

2.4. Aerosol Transport Model Inside the Market. A zone model was developed to estimate the virus concentration and deposition inside Street No. 7 of the market using the above viral shedding and biologic decay data. The zone model assumed that the virus concentration was homogeneous due to the mixing by human movements. The variation of the airborne concentration of active viruses inside the market was controlled by the following relation:

$$
\begin{aligned}
V_{\mathrm{m}} \frac{d c}{d t}= & -\left(Q+v_{\mathrm{dv}} \times S_{\mathrm{v}}+v_{\mathrm{du}} \times S_{\mathrm{u}}+v_{\mathrm{dd}} \times S_{\mathrm{d}}\right. \\
& \left.+\lambda \times V_{\mathrm{m}}\right) \times c+\sigma \\
c(0)= & 0
\end{aligned}
$$

where $V_{\mathrm{m}}$ is the inner volume of Street No. 7, $c\left(\mathrm{PFU} \mathrm{m} \mathrm{m}^{-3}\right)$ is the viral concentration, $Q$ is the ventilation rate $\left(\mathrm{m}^{3} \mathrm{~s}^{-1}\right) ; S_{\mathrm{v}}$ $S_{\mathrm{u}}$ and $S_{\mathrm{d}}$ are the areas $\left(\mathrm{m}^{2}\right)$ of vertical, upward-facing, and downward-facing surfaces of Street No. 7, respectively; $v_{\mathrm{dv}}, v_{\mathrm{du}}$, and $v_{\mathrm{dd}}$ are deposition velocities $\left(\mathrm{m} \mathrm{s}^{-1}\right)$ for the corresponding surface; $\lambda$ is the biologic decay rate of the virus $\left(\mathrm{s}^{-1}\right)$; and $\sigma$ is the viral shedding rate $\left(\mathrm{PFU} \mathrm{s} \mathrm{s}^{-1}\right)$. The airflow was hourly updated. The concentration inside Street No. 7 at hour $t$ was calculated as 
(a)

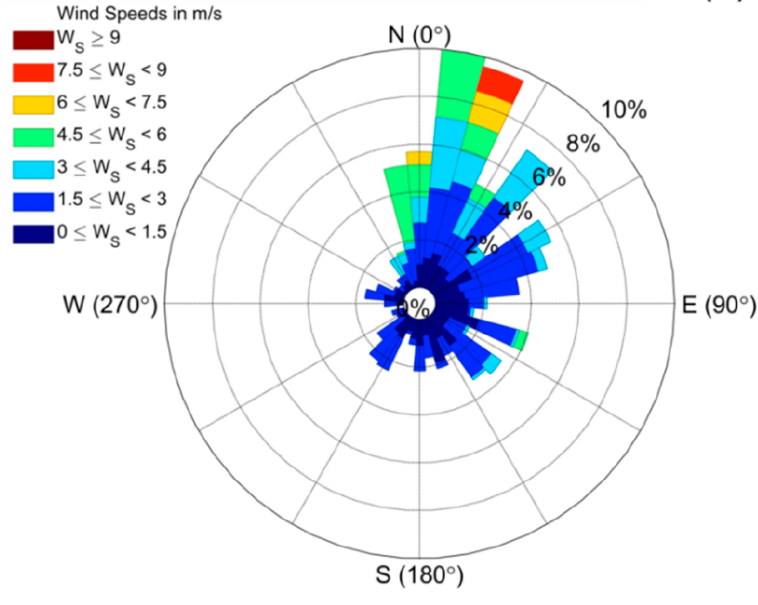

(c)

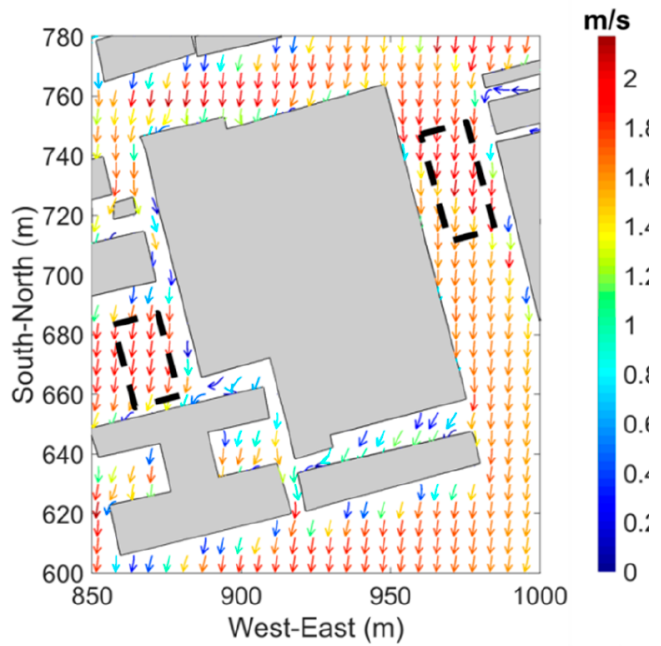

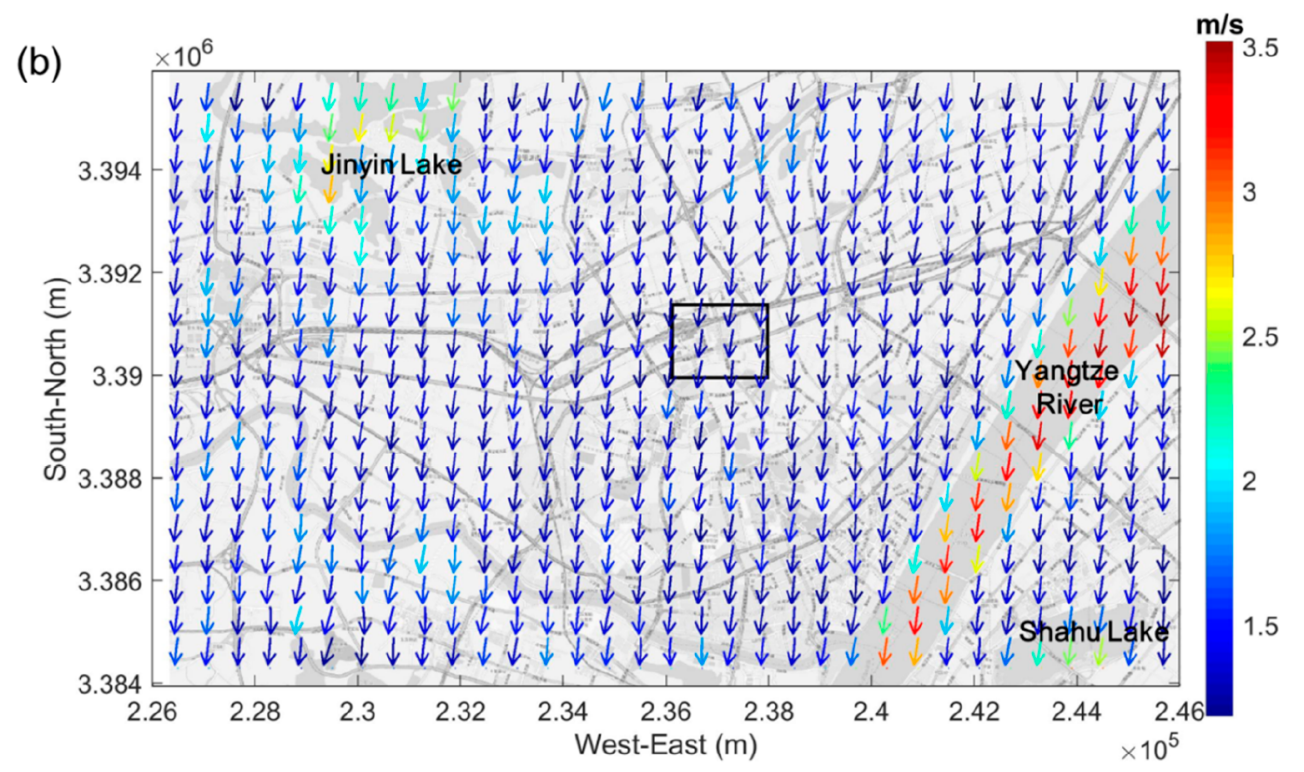

Figure 2. (a) Wind distribution at $10 \mathrm{~m}$ above ground in Wuhan in December, 2019. (b) Wind field calculated by GRAMM (Graz Mesoscale Model wind fields) in the vertical first layer $(10 \mathrm{~m})$. (c) The black boxes were utilized to calculate the reference wind for the airflow network (AFN) analysis in the market street.

$$
\begin{aligned}
c_{t}= & \frac{1}{\dot{V}_{\text {loss }}} \times\left(1-\exp \left(\frac{-\dot{V}_{\text {loss }} \times \Delta t}{V_{\mathrm{m}}}\right)\right) \times \sigma+c_{t-\Delta t} \\
\quad & \exp \left(\frac{-\dot{V}_{\text {loss }} \times \Delta t}{V_{\mathrm{m}}}\right) \\
\dot{V}_{\text {loss }}= & Q+v_{\mathrm{dv}} \times S_{\mathrm{v}}+v_{\mathrm{du}} \times S_{\mathrm{u}}+v_{\mathrm{dd}} \times S_{\mathrm{d}}+\lambda \times V_{\mathrm{m}}
\end{aligned}
$$

The ventilation rate $Q$ was estimated using the airflow network (AFN) analysis, following the method proposed by Karava et al. ${ }^{54}$ The deposition velocities were estimated following the method proposed by Lai et al. ${ }^{37}$ The detailed methods are introduced in the Supporting Information.

2.5. Atmospheric Dispersion Model. The atmospheric dispersion in the ambient environment was calculated using the coupled model system of GRAMM/GRAL ${ }^{38}$ (version 19.03), where GRAMM (Graz Mesoscale Model wind fields) is an Eulerian mesoscale numerical weather prediction model and
GRAL (microphysics Graz Lagrangian Model) is a Lagrangian dispersion model. The model system was designed to reproduce the atmospheric transport of pollutants in complex terrain, e.g., the inner-Alpine basins. It has already been utilized to simulate NOx and particulate matter concentrations with high resolution in Zurich. ${ }^{55}$

The computational domain of the GRAMM model is shown in Figure 1a. The size of the domain was about $20 \mathrm{~km}$ (westeast) $\times 12 \mathrm{~km}$ (south-north), with a horizontal resolution of $300 \mathrm{~m}$. There were 15 layers in the vertical direction. The thickness of the first layer was $10 \mathrm{~m}$, and the vertical stretching factor was 1.4. The height of the domain was $3874 \mathrm{~m}$. The GRAMM model was driven by the reanalysis meteorological data, 0.25 Degree Global Forecast Grids Historical Archive, provided by the Global Forecast System (GFS) of the National Centers for Environmental Prediction (NCEP). ${ }^{56}$ The topography data were from the Shuttle Radar Topography Mission (SRTM) digital elevation data with 1 arc-second resolution. ${ }^{57}$ The land cover data were from the Finer 
Resolution Observation and Monitoring of Global Land Cover (FROM-GLC) $2017 \mathrm{v} 1$ with $30 \mathrm{~m}$ resolution. ${ }^{58}$ The building data were acquired from Baidu Map.

The GRAL model utilized the GRAMM data to further calculate the wind flow and aerosol dispersion inside the area populated by buildings. The computational domain of GRAL is shown in Figure 1a. The domain was about $1.86 \mathrm{~km}$ (westeast) $\times 1.43 \mathrm{~km}$ (south-north), with a horizontal resolution of $2 \mathrm{~m}$ and 163 vertical layers. The thickness of the first layer was $2 \mathrm{~m}$, and the stretching factor was 1.01. The height of the domain was $813 \mathrm{~m}$, about 5 times higher than the tallest building in the domain.

2.6. Dose-Response Model. The dose-response relation is normally utilized to assess the infection risk as a function of the exposure dose. However, there is no available information about the dose-response relation for SARS-CoV-2. SARSCoV-2 and SARS-CoV share the same host cell receptor angiotensin-converting enzyme 2 (ACE2), and they also share similar profiles of cellular tropism, ${ }^{59}$ indicating commonalities between the infectivity of these two viruses. ${ }^{60}$ As a result, the exponential model developed by Watanabe et al. ${ }^{39}$ for SARS$\mathrm{CoV}$ could be a reasonable surrogate for the infection risk assessment in this study. The exponential model is expressed as

$$
p(d)=1-\exp \left(-\frac{d}{k}\right)
$$

where $p(d)$ is the infection risk at a dose of $d$ in units of plaque-forming units (PFU) and $k$ is a pathogen dependent parameter, which was optimally estimated as $4.1 \times 10^{2} \mathrm{PFU}$ for SARS-CoV based on the data for the infection of transgenic mice susceptible to SARS-CoV. ${ }^{39}$ The study ${ }^{39}$ also estimated that $k$ ranged between 10 and $10^{4}$ PFU based on the experiments challenging humans or mice with different coronaviruses, including HCoV-229E, ${ }^{61} \mathrm{MHV}-\mathrm{S},{ }^{62} \mathrm{MHV}-2,{ }^{63}$ and HEV-67N. ${ }^{64,65}$ In order to fully consider the uncertainties, we adopted the distribution $\log _{10}(k) \sim N\left(\log _{10}(410)\right.$, $\left.\log _{10}(410 / 20) / 3\right)$ for $k$. The lower end the distribution was about $20 \mathrm{PFU}$, with infectivity 20 times higher than the optimal value. The dose $d$ was estimated by

$$
d=\sum_{i=1}^{n} \int_{t_{0}}^{t} N_{\text {resp }} \times V_{\text {tidal }} \times c_{\text {air }, i}(t) \times f_{\text {dep }, i} \mathrm{~d} t
$$

where $N_{\text {resp }}$ is the total number of respirations (20 times per minute), $V_{\text {tidal }}$ is the tidal volume $(500 \mathrm{~mL}$ per inspiration), $c_{\mathrm{air}, i}(t)$ is the airborne virus concentration carried by the particles in size bin $i$, and $f_{\text {dep }}$ is the deposition fraction of the particles in size bin $i$ in the human respiratory tract, including anterior nasal, naso-oropharynx/larynx, bronchi, bronchioles, and alveolar interstitial. The deposition fraction $f_{\text {dep }}$ was calculated using the deposition model for pathogenic bioaerosols, ${ }^{66}$ as shown in Figure S2.

\section{RESULTS AND DISCUSSION}

3.1. Meteorological Condition. The average temperature in Wuhan was about 6 to $10{ }^{\circ} \mathrm{C}$ in December, and the relative humidity was about $75 \%$. Figure 2 a shows the distribution of wind speed and direction at $10 \mathrm{~m}$ above the ground. Wuhan was mainly dominated by north and northeast winds in December 2019, with most of the wind speed below $6 \mathrm{~m} \mathrm{~s}^{-1}$. Figure $2 \mathrm{~b}$ shows the GRAMM results for the most dominant wind scenario with a speed of about $5 \mathrm{~m} \mathrm{~s}^{-1}$, a direction of $8^{\circ}$, and neutral atmospheric stability, accounting for about $3.62 \%$ of all meteorological conditions. The wind direction was nearly the same in the whole area due to the relatively flat terrain, but the wind speed was much higher above water surfaces, e.g., the Yangtze River and lakes, due to the low surface roughness.

The GRAL model was applied for detailed wind and dispersion calculations considering the effects of buildings with a resolution of $2 \mathrm{~m}$. The black box in Figure $2 \mathrm{~b}$ indicates the computational domain of the GRAL calculation. Figure $2 c$ shows the results of GRAL for the wind field among the buildings near the market driven by the data from GRAMM in Figure $2 \mathrm{~b}$. The wind was nearly homogeneous except for the area near walls due to friction. The reference wind speed and direction for the windward and leeward facades in the airflow analysis to estimate the natural ventilation were calculated as averages within the black-dashed boxes in Figure 2c.

3.2. Influence Factors for Air Concentrations Inside Street No. 7. Four different cases were calculated to investigate the influences of particle size on the virus concentrations inside the market. The virus containing particles were assumed to be monodisperse in the four cases, with a diameter of $0.8,1.8,3.5$, and $5.5 \mu \mathrm{m}$, which could be suspended in the air for a relatively long time. Most of the particles generated by normal breathing were within this range. ${ }^{45}$ In all cases, one infected patient was assumed to be inside the market from 6:00 to 18:00 each day, with viral shedding rates of $50 \mathrm{PFU}$ per hour, and the half-life periods were set as $12 \mathrm{~h}$.

Figure 3a shows the results on two typical days, December 12 and 13. The air flow speeds inside Street No. 7 were about $0.5 \mathrm{~cm} \mathrm{~s}^{-1}$ and $0.2 \mathrm{~cm} \mathrm{~s}^{-1}$ on these 2 days. The results indicated that the concentration started to increase from 6:00 in the morning after the arrival of the infected person and decreased in the evening after 18:00 due to the lack of viral shedding, the deposition, the biologic degradation, and the ventilation. Large particles (e.g., $5.5 \mu \mathrm{m}$ ) had a lower concentration and rapidly reached equilibrium due to the higher deposition rate. Small particles were more difficult to remove from the air, so the concentration was higher and it constantly increased during the day with insufficient ventilation on December 13. The large particles (3.5 and $5.5 \mu \mathrm{m}$ ) were commonly completely removed from the air during the nights, but some of the small particles $(0.8$ and $1.8 \mu \mathrm{m})$ were able to remain suspended in the air.

The other four similar cases were also calculated to investigate the influences of the viral biologic decay on the concentration. The particles were monodisperse with a diameter of $3.5 \mu \mathrm{m}$ in these cases with half-life periods of 1 , 12,24 , and $70 \mathrm{~h}$, covering the range of reported values for coronaviruses. The viral shedding was the same with the previous cases. The results are shown in Figure $3 \mathrm{~b}$. Faster degradation, e.g., a $1 \mathrm{~h}$ half-life period, led to much lower concentration. The biologic decay only had marginal influences on airborne virus concentrations when the half-life period was longer than $12 \mathrm{~h}$.

3.3. Air Concentrations inside Street No. 7 and Release into the Ambient Environment. Monte Carlo (MC) simulations were conducted to investigate the airborne virus concentration inside Street No. 7 and the release into the outdoor environment using polydisperse particles, considering the uncertainties in the viral shedding and the biologic decay. Figure $4 \mathrm{a}$ shows the MC results of the airborne virus concentrations inside the market. The data for the whole month are shown in Figure S3 in the SI. The median 
(a)

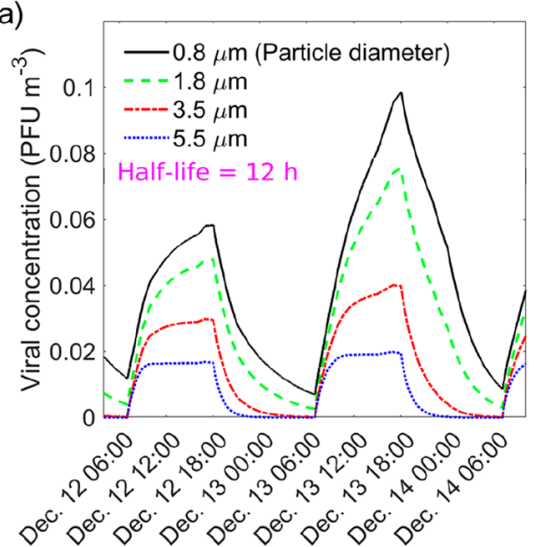

(b)

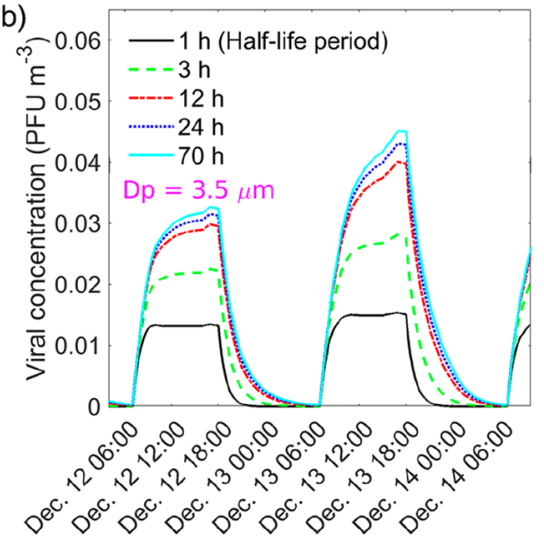

Figure 3. Viral concentration inside the market with natural ventilation: (a) influences of the particle diameters; (b) influences of the biologic decay, represented by the half-life periods.
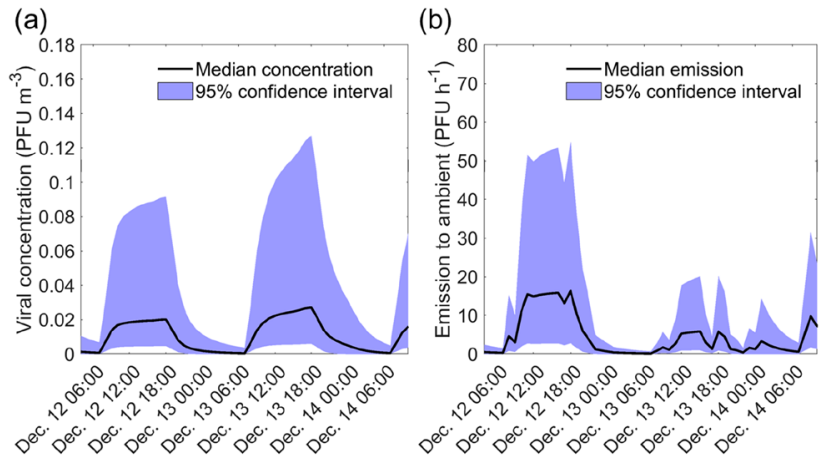

Figure 4. (a) Airborne virus concentration in Street No. 7 of the market; (b) release rates of the virus into the ambient environment.

concentrations were close to those of large particles (3.5 and $5.5 \mu \mathrm{m})$ as shown in Figure 3. It was suggested that breath aerosols were generated by fluid film ruptures in lungs during inhalation due to the expansion of the bronchiole, ${ }^{67}$ so the viral shedding was proportional to the particle volume as shown in eq 1 . The viral shedding within the investigated range $(<5.5$ $\mu \mathrm{m}$ ) was dominated by the large particles due to the high volume, in spite of their low number concentrations, based on the assumption of homogeneous viral concentration in respiratory fluid. It should be noted that the assumption maybe was not valid for large droplets $(>5.5 \mu \mathrm{m})$, which could have different generation mechanisms. Some studies have shown that the viral shedding in droplets was comparable with that in aerosols. ${ }^{48,49}$ In the MC simulations, most of the halflife periods were several hours, following the available biologic decay data of coronavirus. ${ }^{51-53}$ The $95 \%$ confidence intervals of the MC simulations were shown as the shaded areas, which indicated the influences of the uncertain viral shedding and biologic decay. The virus inside the market was transported into the outdoor environment by natural ventilation. As shown in Figure 4, the virus release is generally anticorrelated with the airborne concentration in Street No. 7 of the market.

3.4. Outdoor Concentration Due to Atmospheric Dispersion. The estimated release of virus into the ambient environment was utilized as the source term for the atmospheric dispersion calculations in the GRAL model. The source was at the outlet of the indoor flow, either the western or the eastern exit of the market street, which was dependent on the ambient wind direction. The area was dominated by north and northeast wind as shown in Figure 2a, so the virus was primarily released from the western exit. Figure 5a displays the three-dimensional isosurface of $10^{-6} \mathrm{PFU} \mathrm{m}{ }^{-3}$, to show the interaction between the plume and the surrounding buildings, in the most dominant wind scenario shown in Figure 2. The plume was initially horizontally transported above the parking lot by the wind among the buildings. The expanding width of the plume indicated rapid dilution. The virus was confined

(a)

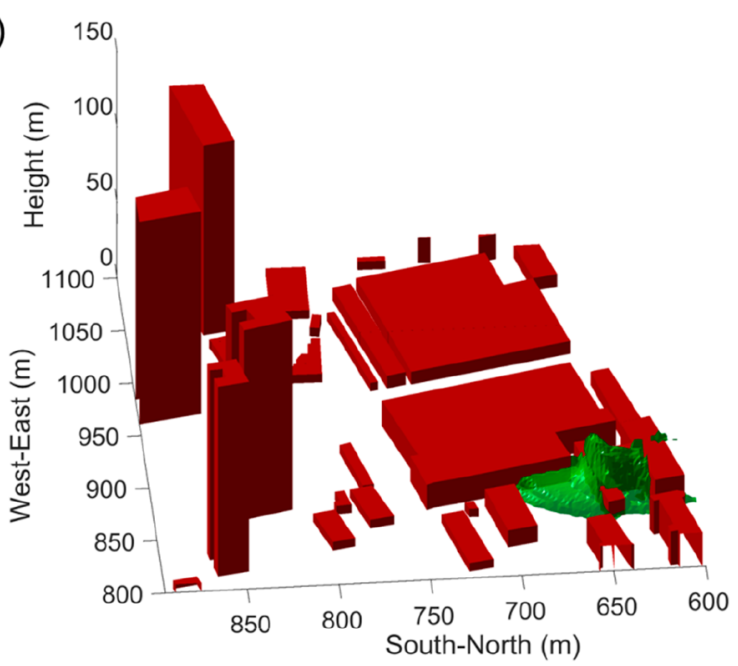

(b)

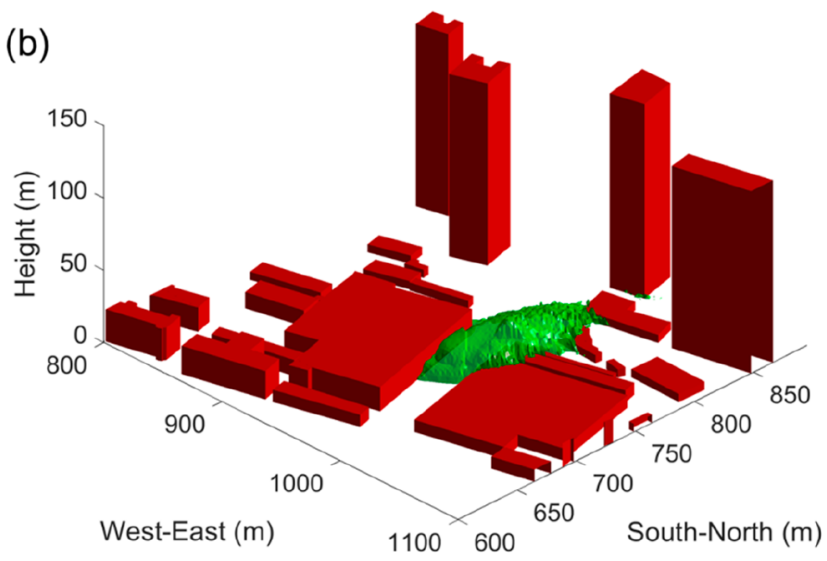

Figure 5. Three dimensional $10^{-6} \mathrm{PFU} \mathrm{m} \mathrm{m}^{-3}$ isosurfaces: (a) the plume emitted from the western exit caused by $5 \mathrm{~m} \mathrm{~s}^{-1}$ north wind $\left(8^{\circ}\right)$ at $10 \mathrm{~m}$ above ground; (b) the plume emitted from the eastern exit caused by $2.5 \mathrm{~m} \mathrm{~s}^{-1}$ southwest wind $\left(210^{\circ}\right)$. 

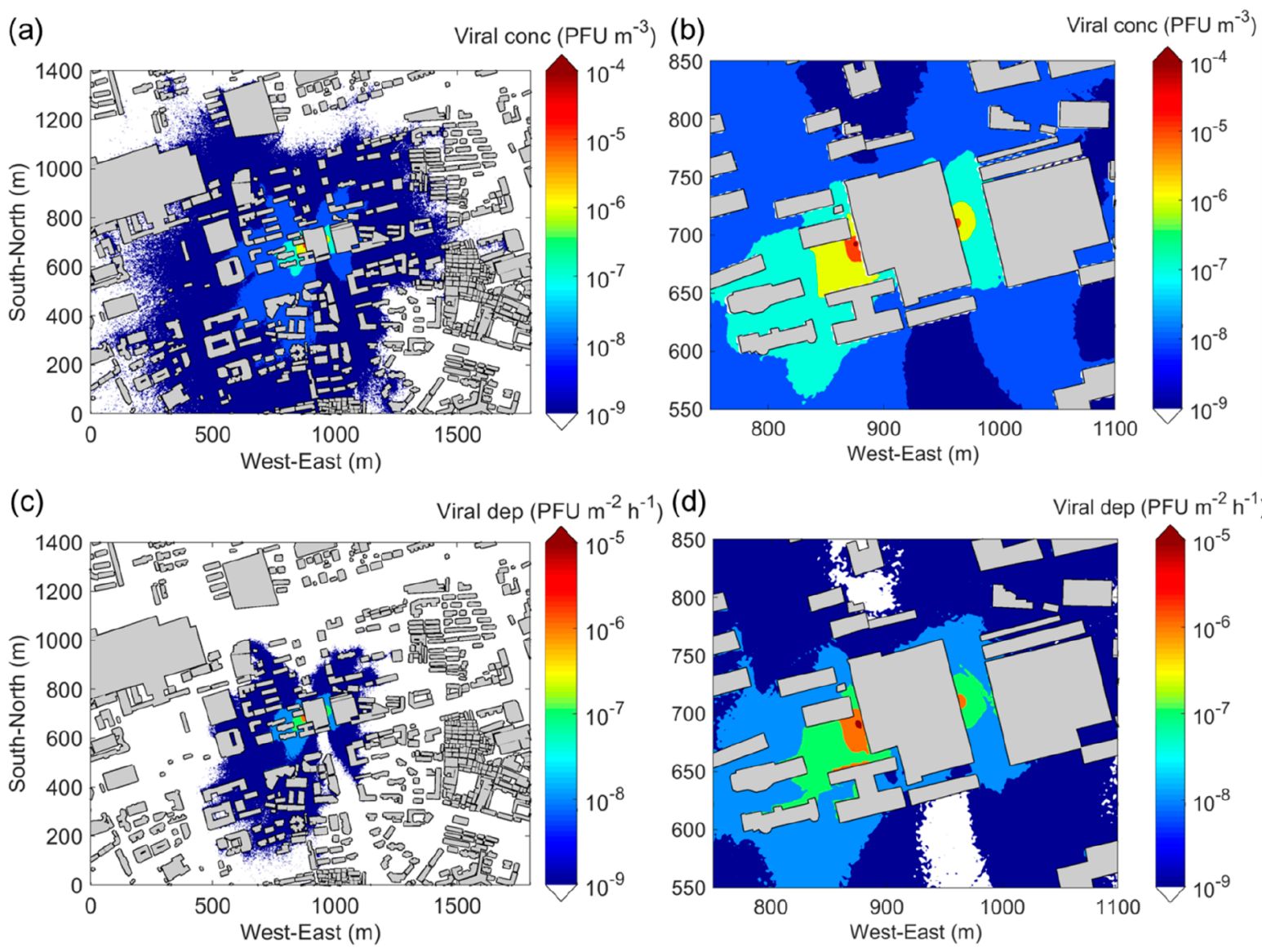

Figure 6. Atmospheric transport of the virus containing aerosol outside the market: (a and b) airborne concentration, (c and d) ground deposition.

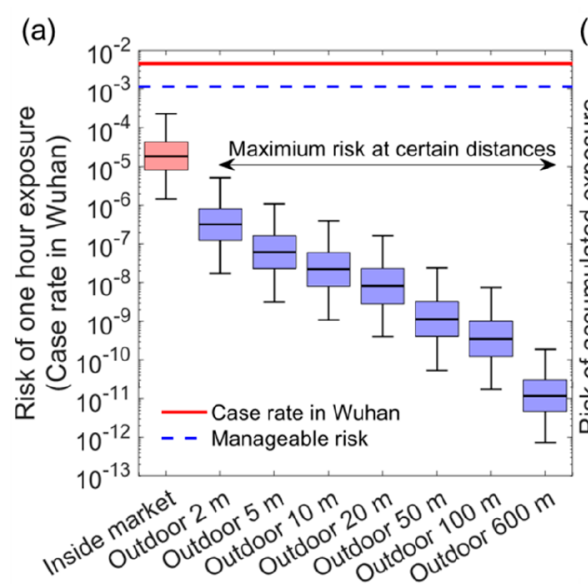

(b)

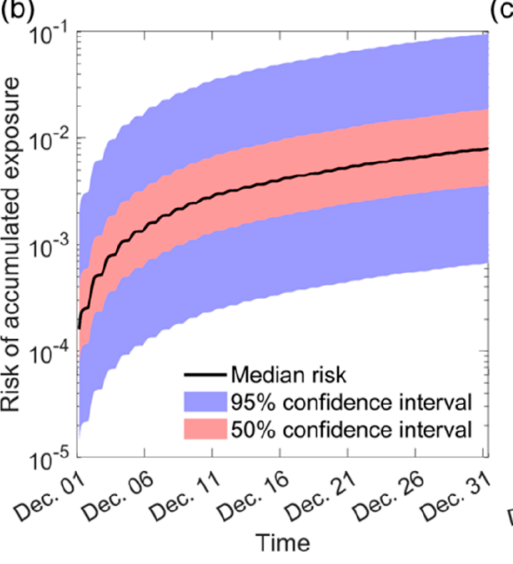

(c)

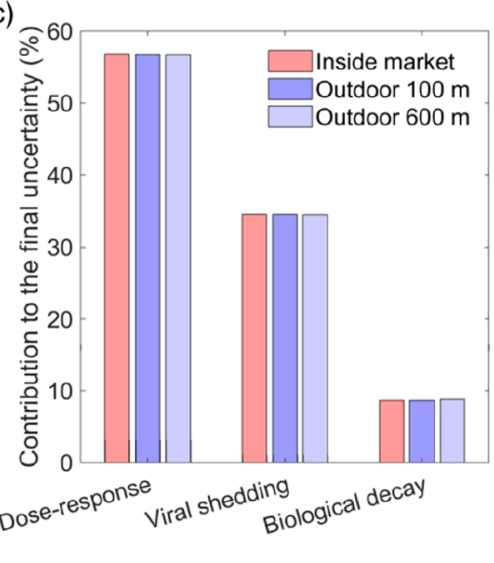

Figure 7. Infection risk through aerosol transmission: (a) infection risk for $1 \mathrm{~h}$ exposure, the band inside the box was the median, the lower and upper boundaries of the box were respectively the first (25th percentile) and third quartiles (75th percentile), and the ends of the whiskers here represented the 2.5 th and 97.5 th percentiles. The outdoor risk was estimated by the assumption of standing in the downwind direction, namely, the maximum risk at a certain distance. (b) Risk for prolonged exposure inside the market, e.g., for shopkeepers working inside the market day after day. (c) Contributions of the uncertain parameters to the final uncertainty of the assessment.

near the ground level during the early phase due to the absence of vertical air flow. The plume was then elevated by the building and vertically transported to high altitudes, which decreased the ground level concentration. Figure $5 b$ shows the plume emitted from the eastern exit with $2.5 \mathrm{~m} \mathrm{~s}^{-1}$ southwest wind $\left(210^{\circ}\right)$. The results also indicated that the virus containing plume was near the ground level close to the market.
Figure 6a shows the time averaged (between 6:00 to 18:00 in December 2019) spatial distribution of the virus concentration at $1.5 \mathrm{~m}$ above ground and the ground deposition. The outdoor concentration was orders of magnitude lower than that inside the market due to the strong dilution by the ambient air. The southwestern region had relatively high concentration due to the dominant north and northeast wind. The results also indicated that the outdoor air 
concentration significantly decreased with the increasing distance from the exits. The concentration was about $10^{-4}$ PFU m ${ }^{-3}$ near the market exits, but it decreased to about $10^{-9}$ $\mathrm{PFU} \mathrm{m} \mathrm{m}^{-3}$ in the square in front of the train station, which was about $500 \mathrm{~m}$ to the west of the market. There were intensive concentration gradients near the market exits as shown in Figure $6 \mathrm{~b}$. The concentration decreased by 3 orders of magnitude from $10^{-4} \mathrm{PFU} \mathrm{m} \mathrm{m}^{-3}$ to $10^{-7} \mathrm{PFU} \mathrm{m}{ }^{-3}$ within about $50 \mathrm{~m}$ near the western exit.

The time averaged ground deposition of the virus containing particles is shown in Figure $6 \mathrm{c}$ and d. The most contaminated outdoor area was the parking lot close to the western exit, with deposition rates between $10^{-7}$ and $10^{-5} \mathrm{PFU} \mathrm{m} \mathrm{m}^{-2} \mathrm{~h}^{-1}$. The deposition rate was below $10^{-7} \mathrm{PFU} \mathrm{\textrm {m } ^ { - 2 }} \mathrm{h}^{-1}$ in other areas. The virus could be accumulated if they were able to survive on the surfaces. The current reported survival time was up to several days, namely, $10^{2}$ hours. As a result, the accumulated active virus deposition near the exit could be up to $10^{-3} \mathrm{PFU}$ $\mathrm{m}^{-2}$.

3.5. Infection Risk through Aerosol Transmission. The infection risk was assessed based on the exposure dose $d$ and the exponential dose-response model by Monte Carlo simulations. The uncertainties in three key factors were considered: biologic decay, viral shedding, and dose-response parameter. There were 100 values for each parameter, so 1 million runs were conducted.

Figure $7 \mathrm{a}$ shows the infection risk through aerosol transmission for $1 \mathrm{~h}$ of exposure. It should be noted that the following results were all based on the assumption of one infected person in the market. The risk would be increased if multiple infected persons were simultaneously inside the market. Conversely, the risk would be decreased with less exposure duration. The highest risk was observed inside the market because of the high virus concentration. The median infection risk of SARS-CoV-2 induced by aerosol transmission was $2.23 \times 10^{-5}$, and the $95 \%$ confidence interval $(\mathrm{CI})$ was from $1.90 \times 10^{-6}(2.5 \%$ percentile $)$ to $2.34 \times 10^{-4}(97.5 \%$ percentile) for $1 \mathrm{~h}$ of exposure in Street No. 7 of the market, approximate to the risk of consumers in the market.

The infection risk by aerosol transmission for the pedestrians outside the market rapidly decreased due to dilution by ambient air. Figure 7 a shows the infection risk at 2 to $600 \mathrm{~m}$ away from the market exit if one stands in the downwind direction, namely, the maximum risk at a certain distance. The median risk at $5 \mathrm{~m}$ outside the market was 7.49 $\times 10^{-8}\left(95 \% \mathrm{CI}: 4.12 \times 10^{-9}\right.$ to $\left.1.13 \times 10^{-6}\right)$ for $1 \mathrm{~h}$ of exposure, which was about 2 orders of magnitude lower than the risk inside the market. The Hankou Train Station was about $600 \mathrm{~m}$ away from the market, with a median infection risk of $1.44 \times 10^{-11}\left(95 \% \mathrm{CI}: 9.28 \times 10^{-13}\right.$ to $\left.1.92 \times 10^{-10}\right)$. The infection risk due to accumulated exposure in December was also estimated for the shopkeepers in Street No. 7 as shown in Figure $7 \mathrm{~b}$. The worst case was considered, which assumed that shopkeepers worked inside the market each day from 6:00 to 18:00 and were exposed to the virus-containing aerosols for one month. The final median infection risk through aerosol transmission was $9.76 \times 10^{-3}$ (95\% CI: $9.10 \times$ $10^{-4}$ to $\left.9.69 \times 10^{-2}\right)$. The infection risk through aerosol transmission was considerable for a person with prolonged exposure in the place without sufficient ventilation.

The $95 \%$ confidence interval of the estimated risk normally covered about 2 orders of magnitude, indicating significant uncertainties in the assessment caused by the current limited and uncertain information about SARS-CoV-2. Figure $7 \mathrm{c}$ shows that the dose-response model, viral shedding, and biological decay respectively contributed about $56.8 \%, 34.5 \%$, and $8.7 \%$ to the final uncertainty. The shares of contributions nearly remained the same at different locations, except that the contribution of biological decay slightly increased from $8.66 \%$ in the market to $8.81 \%$ at $600 \mathrm{~m}$ away from the market because decay became more significant with longer transport time. The results suggested that the dose-response relation and viral shedding were the dominant factors for the uncertainties, thus more efforts should be taken to further investigate these factors.

We investigated the reduction of risk by enhancing the air changes per hour $(\mathrm{ACH})$ as shown in Figure 8. The

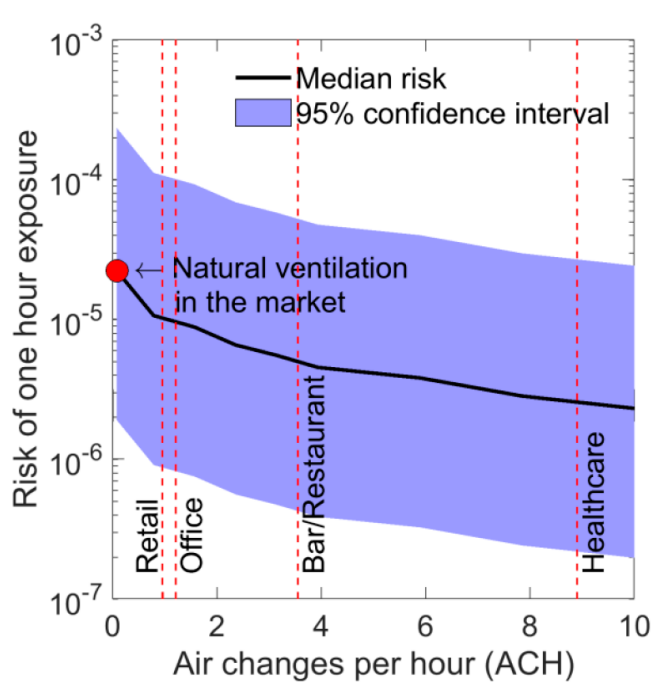

Figure 8. Reduction of infection risk through aerosol transmission by increasing the air changes per hour $(\mathrm{ACH})$ inside the market. The dashed lines mark the typical total $\mathrm{ACHs}$ for retail stores, offices, bars/restaurants, and healthcare facilities. ${ }^{68}$

insufficient ventilation about $0.1 \mathrm{ACH}$ was one important reason for the relatively high risk in the market. The risk could be reduced by half with about $1 \mathrm{ACH}$, a typical value for retail stores and by about 4 times with $3.5 \mathrm{ACHs}$, typical for bars or restaurants. Increasing the ventilation to about $9 \mathrm{ACHs}$, as in healthcare facilities, made the risk about 10 times lower than the situation with natural ventilation. The typical air change rates shown in Figure 8 were the total rates, which included mechanical and natural ventilation rates. ${ }^{68}$ It was reported ${ }^{69}$ that mechanical systems accounted for about $70 \%$ of the total air exchange in retail stores, so mechanical ventilation is an important factor for enhancing the ventilation rates.

\section{IMPLICATIONS}

In this study, the aerosol transmission risk of SARS-CoV-2 was quantitatively assessed based on the current available information about SARS-CoV-2, SARS-CoV, and other coronaviruses. The most probable range (95\% confidence interval) of risk was estimated. The results suggested that the dose-response relation was the dominant factor for the uncertainties, followed by viral shedding. SARS-CoV-2 seems to have stronger transmissibility, and a recent study indicated that SARS-CoV-2 has a higher binding affinity with the host cell receptor (ACE2) than SARS-CoV. ${ }^{70}$ As a result, it 
becomes important to fully consider the uncertainties, e.g., 97.5th percentile, for decision making to keep sufficient safety margins. The uncertainties will remain, until enough information, e.g., the dose-response relation and viral shedding of SARS-CoV-2, are obtained, which could take a long time.

Considering the current uncertainties, the infection risk from aerosol transmission could not be ruled out for the consumers in the poorly ventilated markets. According to the Wuhan Municipal Health Commission, there were 12822 available hospital beds for COVID-19 treatment (Feb. 11, 2020), about $1.17 \times 10^{-3}$ per capita, ${ }^{71}$ shown as the blue dashed line in Figure 7a. In Wuhan, centralized admission in hospitals was required for all confirmed cases. We consider the risk to be manageable if all the expected infected people in Wuhan can be handled by the available medical resources, in other words, if the infection probability is lower than the number of local hospital beds for COVID-19 treatment per capita. The manageable risk could be higher if home quarantine is allowed for patients with mild symptoms. With the assumption of one infected shopkeeper in the market, the 97.5th percentile infection risk by aerosol transmission was about $2.34 \times 10^{-4}$ and could be reduced to about $10^{-4}$ with the typical ventilation rate $(1 \mathrm{ACH})$ as shown in Figure 8, for customers with $1 \mathrm{~h}$ of exposure in poorly ventilated markets similar to the seafood market. The risk was about 5 to 10 times lower than the manageable risk $\left(1.17 \times 10^{-3}\right)$, but it could be increased by several times if multiple infected shopkeepers were simultaneously in the market, becoming close to the manageable risk. As a result, washing hands and social distancing may not be enough for these worst scenarios. We would recommend that people working in poorly ventilated markets wear masks to reduce potential viral shedding, and the consumers could also shorten the time in the markets to keep the risk by aerosol transmission well below the limit of the local medical resources.

About the results presented in this study, it should be noted that only one infected person was assumed to be inside the market, but there might be simultaneously multiple infected people, which could increase the risk. More detailed risk assessment should be further conducted for the aerosol transmission in poorly ventilated markets with multiple infected shopkeepers. The risk estimated here was only through aerosol transmission. The infection risk due to close contact (direct/indirect) and large respiratory droplets by coughs or sneezes or droplets of saliva was not included in this study.

\section{ASSOCIATED CONTENT}

\section{(s) Supporting Information}

The Supporting Information is available free of charge at https://pubs.acs.org/doi/10.1021/acs.est.0c02895.

Wind driven cross ventilation, estimation of the friction velocity inside the market, deposition inside the market, lung deposition, viral concentration in the market in December 2019, Figures S1-S3, and eqs S1-S21 (PDF)

\section{AUTHOR INFORMATION}

\section{Corresponding Author}

Jing Wang - Institute of Environmental Engineering (IfU), ETH

Zürich, Zürich CH-8093, Switzerland; Laboratory for
Advanced Analytical Technologies, Empa, Dübendorf CH-8600, Switzerland; orcid.org/0000-0003-2078-137X; Email: jing.wang@ifu.baug.ethz.ch

\section{Authors}

Xiaole Zhang - Institute of Environmental Engineering (IfU), ETH Zürich, Zürich CH-8093, Switzerland; Laboratory for Advanced Analytical Technologies, Empa, Dübendorf CH-8600, Switzerland

Zheng Ji - Institute of Environmental Engineering (IfU), ETH Zürich, Zürich CH-8093, Switzerland; School of Geography and Tourism, Shaanxi Normal University, Xi'an, Shaanxi 710119, China; International Joint Research Centre of Shaanxi Province for Pollutant Exposure and Eco-Environmental Health, Xi'an, Shaanxi 710119, China

Yang Yue - Institute of Environmental Engineering (IfU), ETH Zürich, Zürich CH-8093, Switzerland; Laboratory for Advanced Analytical Technologies, Empa, Dübendorf CH-8600, Switzerland

Huan Liu - Institute of Environmental Engineering (IfU), ETH Zürich, Zürich CH-8093, Switzerland; Department of Environmental Engineering, Zhejiang University, Hangzhou 310058, China

Complete contact information is available at:

https://pubs.acs.org/10.1021/acs.est.0c02895

\section{Author Contributions}

\#Both authors contributed equally to this work

\section{Notes}

The authors declare no competing financial interest.

\section{ACKNOWLEDGMENTS}

The study was partially supported by the Swiss National Science Foundation (grant number IZLCZ0_189880). We thank Dr. Daisuke Sano (Tohoku University, Japan) and Dr. Toru Watanabe (University of Tokyo, Japan) for their kind suggestions. Z.J. acknowledges the support by China Scholarship Council (No. 201906875037), Natural Science Foundation of Shaanxi Province (2017JQ5074), the Science and Technology Project of Xi'an (2017071CG/ RC034(SXSF002)), and the Fundamental Research Funds for the Central Universities (GK201603075, GK201601009, and GK201802108). H.L. acknowledges the support from the Zhejiang University Scholarship.

\section{REFERENCES}

(1) National_Health_Commission. New Coronavirus Pneumonia Diagnosis and Treatment Plan (trial version 7). http://www.gov.cn/ zhengce/zhengceku/2020-03/04/content_5486705.htm (2020).

(2) Stilianakis, N. I.; Drossinos, Y. Dynamics of infectious disease transmission by inhalable respiratory droplets. J. R. Soc., Interface 2010, 7, 1355-1366.

(3) Fabian, P.; McDevitt, J. J.; DeHaan, W. H.; Fung, R. O. P.; Cowling, B. J.; Chan, K. H.; Leung, G. M.; Milton, D. K. Influenza Virus in Human Exhaled Breath: An Observational Study. PLoS One 2008, 3, e2691.

(4) Yu, I. T. S.; Li, Y.; Wong, T. W.; Tam, W.; Chan, A. T.; Lee, J. H. W.; Leung, D. Y. C.; Ho, T. Evidence of Airborne Transmission of the Severe Acute Respiratory Syndrome Virus. N. Engl. J. Med. 2004, 350, 1731-1739.

(5) Tellier, R. Review of Aerosol Transmission of Influenza. Emerging Infect. Dis. 2006, 12, 1657.

(6) Tellier, R. Aerosol transmission of influenza A virus: a review of new studies. J. R. Soc., Interface 2009, 6, S783-S790. 
(7) Cowling, B. J.; Ip, D. K. M.; Fang, V. J.; Suntarattiwong, P.; Olsen, S. J.; Levy, J.; Uyeki, T. M.; Leung, G. M.; Malik Peiris, J. S.; Chotpitayasunondh, T.; Nishiura, H.; Mark Simmerman, J. Aerosol transmission is an important mode of influenza A virus spread. Nat. Commun. 2013, 4, 1935-1935.

(8) Alraddadi, B. M.; Al-Salmi, H. S.; Jacobs-Slifka, K.; Slayton, R. B.; Estivariz, C. F.; Geller, A. I.; Al-Turkistani, H. H.; Al-Rehily, S. S.; Alserehi, H. A.; Wali, G. Y.; Alshukairi, A. N.; Azhar, E. I.; Haynes, L.; Swerdlow, D. L.; Jernigan, J. A.; Madani, T. A. Risk Factors for Middle East Respiratory Syndrome Coronavirus Infection among Healthcare Personnel. Emerging Infect. Dis. 2016, 22, 1915.

(9) Liu, Y.; Ning, Z.; Chen, Y.; Guo, M.; Liu, Y.; Gali, N. K.; Sun, L.; Duan, Y.; Cai, J.; Westerdahl, D.; Liu, X.; Xu, K.; Ho, K.-f.; Kan, H.; $\mathrm{Fu}, \mathrm{Q}$; Lan, K. Aerodynamic analysis of SARS-CoV-2 in two Wuhan hospitals. Nature 2020, DOI: 10.1038/s41586-020-2271-3.

(10) Courault, D.; Albert, I.; Perelle, S.; Fraisse, A.; Renault, P.; Salemkour, A.; Amato, P. Assessment and risk modeling of airborne enteric viruses emitted from wastewater reused for irrigation. Sci. Total Environ. 2017, 592, 512-526.

(11) Hora, J. d.; Cohim, E. B.; Sipert, S.; Leão, A. Quantitative Microbial Risk Assessment (QMRA) of Campylobacter for RoofHarvested Rainwater Domestic Use. Proceedings 2018, 2, 185.

(12) Jahne, M. A.; Rogers, S. W.; Holsen, T. M.; Grimberg, S. J.; Ramler, I. P. Emission and Dispersion of Bioaerosols from Dairy Manure Application Sites: Human Health Risk Assessment. Environ. Sci. Technol. 2015, 49, 9842-9849.

(13) Zhao, Y.; Richardson, B.; Takle, E.; Chai, L.; Schmitt, D.; Xin, $\mathrm{H}$. Airborne transmission may have played a role in the spread of 2015 highly pathogenic avian influenza outbreaks in the United States. Sci. Rep. 2019, 9, 11755.

(14) Adhikari, U.; Chabrelie, A.; Weir, M.; Boehnke, K.; McKenzie, E.; Ikner, L.; Wang, M.; Wang, Q.; Young, K.; Haas, C. N.; Rose, J.; Mitchell, J. A Case Study Evaluating the Risk of Infection from Middle Eastern Respiratory Syndrome Coronavirus (MERS-CoV) in a Hospital Setting Through Bioaerosols. Risk Anal. 2019, 39, 26082624.

(15) Van Leuken, J. P. G.; Swart, A. N.; Havelaar, A. H.; Van Pul, A.; Van der Hoek, W.; Heederik, D. Atmospheric dispersion modelling of bioaerosols that are pathogenic to humans and livestock - A review to inform risk assessment studies. Microbial Risk Analysis 2016, 1, 1939.

(16) Kritana, P.; Taehyeung, K.; Hyeontae, K.; Ki Youn, K.; Wongeun, S. Atmospheric pathway: A possibility of continuous outbreaks of foot-and-mouth disease in South Korea in 2010-2011. Computers and Electronics in Agriculture 2014, 108, 95-104.

(17) Gloster, J.; Champion, H. J.; Mansley, L. M.; Romero, P.; Brough, T.; Ramirez, A. The 2001 epidemic of foot-and-mouth disease in the United Kingdom: epidemiological and meteorological case studies. Vet. Rec. 2005, 156, 793-803.

(18) Traulsen, I.; Rave, G.; Krieter, J. Sensitivity analysis of a stochastic simulation model for foot and mouth disease. Arch. Anim. Breed. 2010, 53, 529-544.

(19) Traulsen, I.; Krieter, J. Assessing airborne transmission of foot and mouth disease using fuzzy logic. Expert Systems with Applications 2012, 39, 5071-5077.

(20) Sørensen, J. H.; Jensen, C. Ø.; Mikkelsen, T.; Mackay, D. K. J.; Donaldson, A. I. Modelling the atmospheric dispersion of foot-andmouth disease virus for emergency preparedness. Physics and Chemistry of the Earth, Part B: Hydrology, Oceans and Atmosphere 2001, 26, 93-97.

(21) Garner, M. G.; Hess, G. D.; Yang, X. An integrated modelling approach to assess the risk of wind-borne spread of foot-and-mouth disease virus from infected premises. Environmental Modeling \& Assessment 2006, 11, 195-207.

(22) Ssematimba, A.; Hagenaars, T. J.; de Jong, M. C. M. Modelling the Wind-Borne Spread of Highly Pathogenic Avian Influenza Virus between Farms. PLoS One 2012, 7, e31114.

(23) Seo, I.-H.; Lee, I.-B.; Moon, O.-K.; Jung, N.-S.; Lee, H.-J.; Hong, S.-W.; Kwon, K.-S.; Bitog, J. P. Prediction of the spread of highly pathogenic avian influenza using a multifactor network: Part 1 - Development and application of computational fluid dynamics simulations of airborne dispersion. Biosystems Engineering 2014, 121, $160-176$.

(24) Blatny, J. M.; Reif, B. A. P.; Skogan, G.; Andreassen, O.; Høiby, E. A.; Ask, E.; Waagen, V.; Aanonsen, D.; Aaberge, I. S.; Caugant, D. A. Tracking Airborne Legionella and Legionella pneumophila at a Biological Treatment Plant. Environ. Sci. Technol. 2008, 42, 73607367.

(25) Wein, L. M.; Craft, D. L.; Kaplan, E. H. Emergency response to an anthrax attack. Proc. Natl. Acad. Sci. U. S. A. 2003, 100, 43464351.

(26) Stuart, A. L.; Wilkening, D. A. Degradation of Biological Weapons Agents in the Environment: Implications for Terrorism Response. Environ. Sci. Technol. 2005, 39, 2736-2743.

(27) Nicogossian, A.; Schintler, L. A.; Boybeyi, Z. Modeling Urban Atmospheric Anthrax Spores Dispersion: Assessment of Health Impacts and Policy Implications. World Medical \& Health Policy 2011, 3, 1-16.

(28) Wallensten, A.; Moore, P.; Webster, H.; Johnson, C.; van der Burgt, G.; Pritchard, G.; Ellis-Iversen, J.; Oliver, I. Q fever outbreak in Cheltenham, United Kingdom, in 2007 and the use of dispersion modelling to investigate the possibility of airborne spread. Eurosurveillance 2010, 15, 19521.

(29) Roest, H. I. J.; Ruuls, R. C.; Tilburg, J. J. H. C.; NabuursFranssen, M. H.; Klaassen, C. H. W.; Vellema, P.; van den Brom, R.; Dercksen, D.; Wouda, W.; Spierenburg, M. A. H.; van der Spek, A. N.; Buijs, R.; de Boer, A. G.; Willemsen, P. T. J.; van Zijderveld, F. G. Molecular Epidemiology of Coxiella burnetii from Ruminants in $\mathrm{Q}$ Fever Outbreak, the Netherlands. Emerging Infect. Dis. 2011, 17, 668.

(30) Zhang, X.; Raskob, W.; Landman, C.; Trybushnyi, D.; Li, Y. Sequential multi-nuclide emission rate estimation method based on gamma dose rate measurement for nuclear emergency management. $J$. Hazard. Mater. 2017, 325, 288-300.

(31) Zhang, X. L.; Li, Q. B.; Su, G. F.; Yuan, M. Q. Ensemble-based simultaneous emission estimates and improved forecast of radioactive pollution from nuclear power plant accidents: application to ETEX tracer experiment. J. Environ. Radioact. 2015, 142, 78-86.

(32) Snoun, H.; Bellakhal, G.; Kanfoudi, H.; Zhang, X.; Chahed, J. One-way coupling of WRF with a Gaussian dispersion model: a focused fine-scale air pollution assessment on southern Mediterranean. Environ. Sci. Pollut. Res. 2019, 26, 22892-22906.

(33) Zhang, X. L.; Su, G. F.; Chen, J. G.; Raskob, W.; Yuan, H. Y.; Huang, Q. Y. Iterative ensemble Kalman filter for atmospheric dispersion in nuclear accidents: An application to Kincaid tracer experiment. J. Hazard. Mater. 2015, 297, 329-339.

(34) Zhang, X. L.; Su, G. F.; Yuan, H. Y.; Chen, J. G.; Huang, Q. Y. Modified ensemble Kalman filter for nuclear accident atmospheric dispersion: Prediction improved and source estimated. J. Hazard. Mater. 2014, 280, 143-155.

(35) Wang, Y.; Huang, H.; Huang, L.; Zhang, X. Source term estimation of hazardous material releases using hybrid genetic algorithm with composite cost functions. Engineering Applications of Artificial Intelligence 2018, 75, 102-113.

(36) Zhang, X. L.; Chen, J. G.; Su, G. F.; Yuan, H. Y. Study on Source Inversion Technology for Nuclear Accidents Based on Gaussian Puff Model and EnKF. In 10th International Conference on Information Systems for Crisis Response and Management; Comes, T.; Ed.; 2013, pp 634-639.

(37) Lai, A. C. K.; Nazaroff, W. W. Modeling Indoor Particle Deposition from Turbulent Flow onto Smooth Surfaces. J. Aerosol Sci. 2000, 31, 463-476.

(38) Oettl, D.; Almbauer, R. A.; Sturm, P. J. A New Method to Estimate Diffusion in Stable, Low-Wind Conditions. Journal of Applied Meteorology 2001, 40, 259-268.

(39) Watanabe, T.; Bartrand, T. A.; Weir, M. H.; Omura, T.; Haas, C. N. Development of a Dose-Response Model for SARS Coronavirus. Risk Anal. 2010, 30, 1129-1138. 
(40) Ma, X. Review of the decisions in the early stages of the epidemic: three key opportunities that are missing. https://www.yicai. com/news/100518039.html (2020).

(41) Li, Q.; Guan, X.; Wu, P.; Wang, X.; Zhou, L.; Tong, Y.; Ren, R.; Leung, K. S. M.; Lau, E. H. Y.; Wong, J. Y.; Xing, X.; Xiang, N.; Wu, Y.; Li, C.; Chen, Q.; Li, D.; Liu, T.; Zhao, J.; Liu, M.; Tu, W.; Chen, C.; Jin, L.; Yang, R.; Wang, Q.; Zhou, S.; Wang, R.; Liu, H.; Luo, Y.; Liu, Y.; Shao, G.; Li, H.; Tao, Z.; Yang, Y.; Deng, Z.; Liu, B.; Ma, Z.; Zhang, Y.; Shi, G.; Lam, T. T. Y.; Wu, J. T.; Gao, G. F.; Cowling, B. J.; Yang, B.; Leung, G. M.; Feng, Z. Early Transmission Dynamics in Wuhan, China, of Novel Coronavirus-Infected Pneumonia. N. Engl. J. Med. 2020, 382, 1199.

(42) Chinese Center for Disease Control and Prevention. China detects large quantity of novel coronavirus at Wuhan seafood market. http://www.chinacdc.cn/yw 9324/202001/t20200127 211469.html (2020).

(43) Sims, A. C.; Burkett, S. E.; Yount, B.; Pickles, R. J. SARS-CoV replication and pathogenesis in an in vitro model of the human conducting airway epithelium. Virus Res. 2008, 133, 33-44.

(44) de Wilde, A. H.; Falzarano, D.; Zevenhoven-Dobbe, J. C.; Beugeling, C.; Fett, C.; Martellaro, C.; Posthuma, C. C.; Feldmann, H.; Perlman, S.; Snijder, E. J. Alisporivir inhibits MERS- and SARScoronavirus replication in cell culture, but not SARS-coronavirus infection in a mouse model. Virus Res. 2017, 228, 7-13.

(45) Morawska, L.; Johnson, G. R.; Ristovski, Z. D.; Hargreaves, M.; Mengersen, K.; Corbett, S.; Chao, C. Y. H.; Li, Y.; Katoshevski, D. Size distribution and sites of origin of droplets expelled from the human respiratory tract during expiratory activities. J. Aerosol Sci. 2009, 40, 256-269.

(46) Duan, X. Exposure Factors Handbook of Chinese Population (Adults); China Environmental Science Press, 2013.

(47) Nicas, M.; Nazaroff, W. W.; Hubbard, A. Toward Understanding the Risk of Secondary Airborne Infection: Emission of Respirable Pathogens. J. Occup. Environ. Hyg. 2005, 2, 143-154.

(48) Yan, J.; Grantham, M.; Pantelic, J.; Bueno de Mesquita, P. J.; Albert, B.; Liu, F.; Ehrman, S.; Milton, D. K. Infectious virus in exhaled breath of symptomatic seasonal influenza cases from a college community. Proc. Natl. Acad. Sci. U. S. A. 2018, 115, 1081-1086.

(49) Leung, N. H. L.; Chu, D. K. W.; Shiu, E. Y. C.; Chan, K.-H.; McDevitt, J. J.; Hau, B. J. P.; Yen, H.-L.; Li, Y.; Ip, D. K. M.; Peiris, J. S. M.; Seto, W.-H.; Leung, G. M.; Milton, D. K.; Cowling, B. J. Respiratory virus shedding in exhaled breath and efficacy of face masks. Nat. Med. 2020, 26, 676.

(50) Sampath, R.; Hofstadler, S. A.; Blyn, L. B.; Eshoo, M. W.; Hall, T. A.; Massire, C.; Levene, H. M.; Hannis, J. C.; Harrell, P. M.; Neuman, B.; Buchmeier, M. J.; Jiang, Y.; Ranken, R.; Drader, J. J.; Samant, V.; Griffey, R. H.; McNeil, J. A.; Crooke, S. T.; Ecker, D. J. Rapid identification of emerging pathogens: coronavirus. Emerging Infect. Dis. 2005, 11, 373-379.

(51) van Doremalen, N.; Bushmaker, T.; Morris, D. H.; Holbrook, M. G.; Gamble, A.; Williamson, B. N.; Tamin, A.; Harcourt, J. L.; Thornburg, N. J.; Gerber, S. I.; Lloyd-Smith, J. O.; de Wit, E.; Munster, V. J. Aerosol and Surface Stability of SARS-CoV-2 as Compared with SARS-CoV-1. N. Engl. J. Med. 2020, 382, 1564.

(52) Ijaz, M. K.; Brunner, A. H.; Sattar, S. A.; Nair, R. C.; JohnsonLussenburg, C. M. Survival Characteristics of Airborne Human Coronavirus 229E. J. Gen. Virol. 1985, 66, 2743-2748.

(53) Pyankov, O. V.; Bodnev, S. A.; Pyankova, O. G.; Agranovski, I. E. Survival of aerosolized coronavirus in the ambient air. J. Aerosol Sci. 2018, 115, 158-163.

(54) Karava, P.; Stathopoulos, T.; Athienitis, A. K. Airflow assessment in cross-ventilated buildings with operable façade elements. Building and Environment 2011, 46, 266-279.

(55) Berchet, A.; Zink, K.; Oettl, D.; Brunner, J.; Emmenegger, L.; Brunner, D. Evaluation of high-resolution GRAMM-GRAL (v15.12/ v14.8) NOx simulations over the city of Zürich, Switzerland. Geosci. Model Dev. 2017, 10, 3441-3459.

(56) NCEP GFS 0.25 Degree Global Forecast Grids Historical Archive (Research Data Archive at the National Center for
Atmospheric Research, Computational and Information Systems Laboratory. National Centers for Environmental Prediction/National Weather Service/NOAA/U.S. Department of Commerce: Boulder, CO, 2015.

(57) Farr, T. G.; Rosen, P. A.; Caro, E.; Crippen, R.; Duren, R.; Hensley, S.; Kobrick, M.; Paller, M.; Rodriguez, E.; Roth, L.; Seal, D.; Shaffer, S.; Shimada, J.; Umland, J.; Werner, M.; Oskin, M.; Burbank, D.; Alsdorf, D. The Shuttle Radar Topography Mission. Rev. Geophys. 2007, 45, DOI: 10.1029/2005RG000183.

(58) Gong, P.; Liu, H.; Zhang, M.; Li, C.; Wang, J.; Huang, H.; Clinton, N.; Ji, L.; Li, W.; Bai, Y.; Chen, B.; Xu, B.; Zhu, Z.; Yuan, C.; Ping Suen, H.; Guo, J.; Xu, N.; Li, W.; Zhao, Y.; Yang, J.; Yu, C.; Wang, X.; Fu, H.; Yu, L.; Dronova, I.; Hui, F.; Cheng, X.; Shi, X.; Xiao, F.; Liu, Q.; Song, L. Stable classification with limited sample: transferring a $30-\mathrm{m}$ resolution sample set collected in 2015 to mapping $10-\mathrm{m}$ resolution global land cover in 2017. Science Bulletin 2019, 64, 370.

(59) Chu, H.; Chan, J. F.-W.; Yuen, T. T.-T.; Shuai, H.; Yuan, S.; Wang, Y.; Hu, B.; Yip, C. C.-Y.; Tsang, J. O.-L.; Huang, X.; Chai, Y.; Yang, D.; Hou, Y.; Chik, K. K.-H.; Zhang, X.; Fung, A. Y.-F.; Tsoi, H.W.; Cai, J.-P.; Chan, W.-M.; Ip, J. D.; Chu, A. W.-H.; Zhou, J.; Lung, D. C.; Kok, K.-H.; To, K. K.-W.; Tsang, O. T.-Y.; Chan, K.-H.; Yuen, K.-Y. Comparative tropism, replication kinetics, and cell damage profiling of SARS-CoV-2 and SARS-CoV with implications for clinical manifestations, transmissibility, and laboratory studies of COVID-19: an observational study. Lancet Microbe 2020, 1, e14.

(60) Hoffmann, M.; Kleine-Weber, H.; Schroeder, S.; Krüger, N.; Herrler, T.; Erichsen, S.; Schiergens, T. S.; Herrler, G.; Wu, N.-H.; Nitsche, A.; Müller, M. A.; Drosten, C.; Pöhlmann, S. SARS-CoV-2 Cell Entry Depends on ACE2 and TMPRSS2 and Is Blocked by a Clinically Proven Protease Inhibitor. Cell 2020, 181, 271.

(61) Bradburne, A. F.; Bynoe, M. L.; Tyrrell, D. A. Effects of a "new" human respiratory virus in volunteers. $\mathrm{Br} \mathrm{Med}$. J. 1967, 3, 767-769.

(62) Taguchi, F.; Aiuchi, M.; Fujiwara, K. Age-Dependent Response of Mice to a Mouse Hepatitis Virus, MHV-S. Japanese Journal of Experimental Medicine 1977, 47, 109-115.

(63) Hirano, N.; Takenaka, S.; Fujiwara, K. Pathogenicity of Mouse Hepatitis Virus for Mice Depending upon Host Age and Route of Infection. Japanese Journal of Experimental Medicine 1975, 45, 285292.

(64) Hirano, N.; Nomura, R.; Tawara, T.; Tohyama, K. Neurotropism of Swine Haemagglutinating Encephalomyelitis Virus (Coronavirus) in Mice Depending upon Host Age and Route of Infection. J. Comp. Pathol. 2004, 130, 58-65.

(65) Hirano, N.; Haga, S.; Sada, Y.; Tohyama, K. Susceptibility of rats of different ages to inoculation with swine haemagglutinating encephalomyelitis virus (a coronavirus) by various routes. J. Comp. Pathol. 2001, 125, 8-14.

(66) Guha, S.; Hariharan, P.; Myers, M. R. Enhancement of ICRP's Lung Deposition Model for Pathogenic Bioaerosols. Aerosol Sci. Technol. 2014, 48, 1226-1235.

(67) Johnson, G. R.; Morawska, L. The Mechanism of Breath Aerosol Formation. J. Aerosol Med. Pulm. Drug Delivery 2009, 22, 229-237.

(68) Zaatari, M.; Nirlo, E.; Jareemit, D.; Crain, N.; Srebric, J.; Siegel, $\mathrm{J}$. Ventilation and indoor air quality in retail stores: A critical review (RP-1596). HVACR Res. 2014, 20, 276-294.

(69) Bennett, D. H.; Fisk, W.; Apte, M. G.; Wu, X.; Trout, A.; Faulkner, D.; Sullivan, D. Ventilation, temperature, and HVAC characteristics in small and medium commercial buildings in California. Indoor Air 2012, 22, 309-320.

(70) Wrapp, D.; Wang, N.; Corbett, K. S.; Goldsmith, J. A.; Hsieh, C.-L.; Abiona, O.; Graham, B. S.; McLellan, J. S. Cryo-EM structure of the 2019-nCoV spike in the prefusion conformation. Science 2020, $367,1260$.

(71) Wuhan_Municipal_Health_Commission. The use of hospital beds in designated hospitals for COVID-19 in the city. http://wjw. wuhan.gov.cn/front/web/showDetail/2020021209536 (2020). 